\title{
SALIVARY FLOW RATE, ORAL YEAST COLONIZATION AND DENTAL STATUS IN INSTITUTIONALIZED AND NON-INSTITUTIONALIZED ELDERLY
}

\author{
Irena Glažar ${ }^{1}$, Miranda Muhvić Urek ${ }^{1}$, Davor Kuiš ${ }^{1}$, Jelena Prpić ${ }^{1}$, Ivana Mišković ${ }^{1}$, \\ Daniela Kovačević Pavičić ${ }^{2}$ and Sonja Pezelj-Ribarić ${ }^{1}$ \\ ${ }^{1}$ Department of Oral Pathology and Periodontology, \\ ${ }^{2}$ Department of Prosthodontics, School of Dental Medicine, University of Rijeka, Rijeka, Croatia
}

SUMMARY - Elderly people, especially those institutionalized in long-term care facilities, are at risk of various oral diseases. The aim of the study was to determine the incidence of hyposalivation and colonization/oral fungal infection of oral cavity with yeasts, as well as dental status in institutionalized and non-institutionalized elderly. The study included 280 institutionalized and 61 non-institutionalized elderly people. Salivary flow rate, oral colonization with yeasts/oral infection and dental status were assessed and compared between the groups. The institutionalized elderly had a significantly lower salivary flow rate $(\mathrm{p}=0.035)$. Oral colonization with yeasts was more frequently found in institutionalized elderly $(\mathrm{p}<0.001)$ as compared with non-institutionalized elderly. A negative correlation was found between decreased salivary flow rate and oral yeast colonization and oral fungal infection in both the institutionalized $(r s=-0.58 ; \mathrm{p}<0.05)$ and non-institutionalized ( $r s=-0.52 ; \mathrm{p}<0.05)$ groups. A significant difference in DMFT index was observed between the two groups ( $\mathrm{p}<0.001)$. A negative correlation between decreased salivary flow rate and dental status was found in both the institutionalized $(r s=-0.22 ; p<0.05)$ and non-institutionalized $(r s=-0.56 ; p<0.05)$ groups. The results revealed a significantly higher level of hyposalivation and oral yeast colonization and poorer dental status in the institutionalized group as compared with the non-institutionalized group of elderly people.

Key words: Elderly; Xerostomia; Yeasts; Mouth diseases; DMF index

\section{Introduction}

The proportion of elderly people in the population is increasing worldwide. Some are unable to live independently as a result of their age and/or disease, and require institutionalization in long-term care facilities $^{1,2}$. Multiple systemic diseases and their treatments can impair oral health and, consequently, the quality of life of an elderly person ${ }^{3-5}$. The most common oral diseases among the elderly are dental caries, tooth loss,

Correspondence to: Assist. Prof. Irena Glažar, DMD, PhD, Department of Oral Pathology and Periodontology, School of Dental Medicine, University of Rijeka, Krešimirova 40, HR-51000 Rijeka, Croatia

E-mail: irena.glazar@medri.uniri.hr

Received December 12, 2014, accepted April 19, 2016 gingivitis, periodontitis, decreased salivary flow, candidiasis, and oral cancer ${ }^{2,6}$. These are even more significant among institutionalized elderly people ${ }^{7,8}$. Prevention of oral diseases is greatly influenced by salivary flow; furthermore, saliva protects the oral mucosa and the teeth, plays a role in taste perception, food-bolus formation, swallowing, communication and digestion'. The effect of aging on salivary flow is still unclear, and it seems that it is mainly the unstimulated salivary flow rate that is affected ${ }^{10}$. However, unstimulated salivary flow rate decreases with an increase in the number of medications, in particular following the intake of antihypertensive agents, tranquillizers, sedatives, hypnotics or antipsychotic agents ${ }^{11,12}$. Most of the elderly take at least one medication that adversely affects salivary gland secretion and many of these medications reduce 
salivary flow rate ${ }^{3,13,14}$. Reduced salivary flow rate or hyposalivation is connected with an increased number of microorganisms in the oral cavity resulting in an increased risk of fungal infections and dental caries. Patients become more susceptible to oral fungal infections caused by Candida species (Candida spp.) ${ }^{15,16}$. Nursing home residents are considered particularly susceptible to oral Candida infections because they are usually immunocompromised due to their medical conditions that precipitated their nursing home admission ${ }^{17}$. Another frequent infection among institutionalized persons is dental caries, which is common among today's elderly due to the high prevalence of retained natural teeth and previously restored dental surfaces ${ }^{18}$. Without sufficient saliva to restore oral $\mathrm{pH}$ and to regulate bacterial populations, the oral cavity becomes rapidly colonized with caries-associated $\mathrm{mi}-$ croorganisms ${ }^{19}$.

This study was carried out with the aim of evaluating the salivary gland function, colonization of the oral cavity with yeasts and dental status in the institutionalized and non-institutionalized elderly. In addition, we investigated whether there was a correlation between unstimulated salivary flow rate and colonization with oral yeasts, as well as dental status.

\section{Subjects and Methods}

The study included two groups of elderly subjects over 60 years of age, i.e. institutionalized elderly residing in a nursing home in Rijeka and non-institutionalized elderly. The study plan was approved by the Ethics Committee of the School of Medicine, University of Rijeka and Rijeka University Hospital Center in Rijeka, Croatia. Ethical guidelines of the Declaration of Helsinki were followed. All participants gave their informed consent to participate in the study.

A sample of 350 institutionalized elderly and 200 non-institutionalized elderly were randomly selected. The elderly in the institutionalized group who were bedridden or too ill or unable to communicate were excluded from the study, while twelve persons refused to participate in the study. Similarly, the elderly in the non-institutionalized group who were not interested to participate in the study because they were busy or considered their oral health was fine were excluded from the study.
A total of 341 elderly subjects were included, 280 institutionalized (134 male and 146 female, mean age $72.7 \pm 8.4$ years) and 61 non-institutionalized ( 23 male and 38 female, mean age $70.4 \pm 6.2$ years).

The mouth of each participant was examined. The examination of the institutionalized elderly was performed at bedside using a dental mirror, spatula and artificial light source. The non-institutionalized elderly were examined in a normally equipped dental unit at the Rijeka University Hospital Center, Department of Dental Medicine, by the same dentist examining the institutionalized elderly.

Unstimulated whole saliva was measured by sialometry ${ }^{20}$. Saliva samples were collected from all subjects between 9 a.m. and 11 a.m. Tests of salivary flow rates were performed after the subjects swallowed in order to clear the mouth of any accumulated saliva. Saliva was collected when the participant was positioned in a relaxed position leaning slightly forward. Participants were asked to bend their head forward and spit into a graded tube through a funnel (Copan, Zagreb, Croatia). Collection time was ten minutes and salivary flow rates were calculated as milliliters per minute. In some cases, the collection time was reduced or extended (ranging 5-15 minutes). Subjects with complete or partial removable dentures kept them in their mouth during saliva collection. The unstimulated salivary flow was considered normal at values $\geq 0.36 \mathrm{~mL}$ per minute, low at values ranging from 0.16 to $0.35 \mathrm{~mL}$ per minute, and hyposalivation at values $<0.15 \mathrm{~mL}$ per minute ${ }^{21}$.

Mucosal swabs were obtained from oral mucosa with sterile cotton swabs (Copan, Zagreb, Croatia) and were immediately inoculated on the conventional Sabouraud dextrose agar (PanreacQuimica, Cultimed, Spain). Cultures were aerobically incubated at $37^{\circ} \mathrm{C}$ for 48 hours. In case of no growth, the plates were considered negative after this period and discarded. Cultures of yeast colonies were quantified according to the following scale: no colonies, 1-9 colonies, 10-24 colonies, 25-100 colonies, >100 colonies, and confluent growth according to Olsen ${ }^{22}$. Diagnosis of fungal infection was established after positive yeast culture.

Dental status was assessed by clinical examination that consisted of visual and tactile oral and dental examination in accordance with the World Health Organization (WHO) guidelines. The examinations were performed with a mouth mirror and dental probe. The 
number of teeth that were present and the number of decayed/missing/filled teeth (DMFT index) were recorded following the WHO oral health assessment form ${ }^{23}$.

Statistical analysis of data was performed using Statistica for Windows, release 6.1 (StatSoft, Inc., Tulsa, OK). The Kolmogorov-Smirnov normality test was applied to all data. The $\chi^{2}$-test was used to compare distribution of salivary flow rates and colonization with oral yeasts, while T-test for proportions was applied to compare salivary flow rates and DMFT index between the investigated groups. Spearman's correlation coefficient was used to analyze the relationship between salivary flow rate and colonization with oral yeasts and DMFT values. A value of $\mathrm{p}<0.05$ was considered significant.

\section{Results}

Figure 1 illustrates the results of unstimulated salivary flow rates in the institutionalized and non-institutionalized elderly. Hyposalivation was found to be more common in the institutionalized elderly than in their non-institutionalized counterparts $(\mathrm{p}=0.035)$.

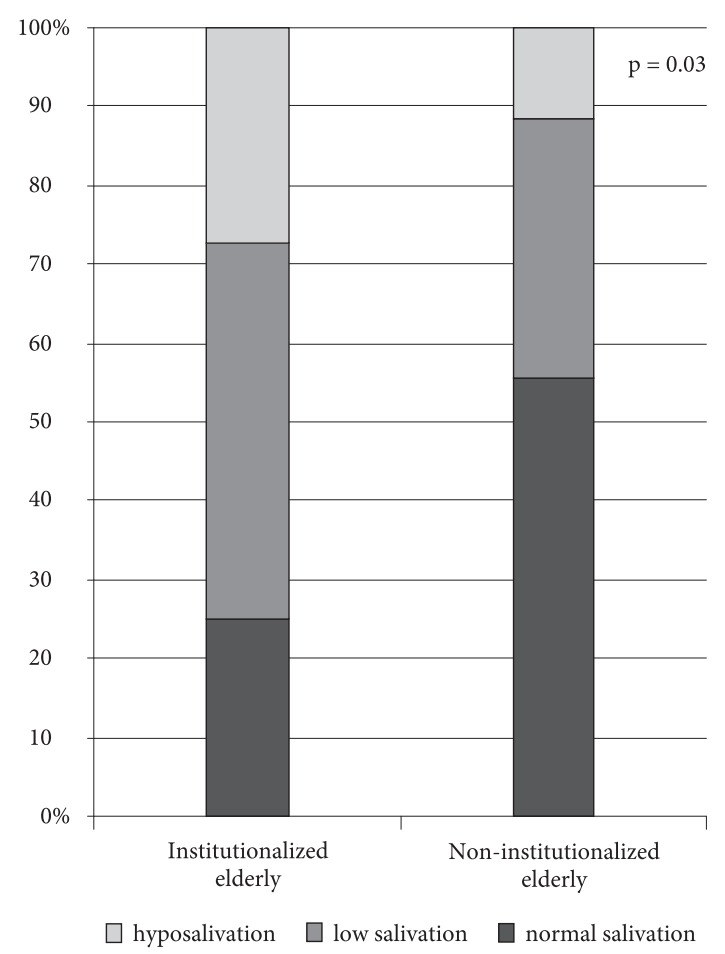

Fig. 1. Distribution of salivary flow rates

in institutionalized and non-institutionalized elderly.
Table 1. Distribution of oral yeast colonization and oral fungal infection in institutionalized and non-institutionalized elderly

\begin{tabular}{|l|c|c|c|}
\hline & $\begin{array}{c}\text { Institu- } \\
\text { tionalized } \\
\text { elderly } \\
\mathrm{n}(\%)\end{array}$ & $\begin{array}{c}\text { Non- } \\
\text { institu- } \\
\text { tionalized } \\
\text { elderly } \\
\mathrm{n}(\%)\end{array}$ & p-value \\
\hline $\begin{array}{l}\text { Negative test } \\
\text { result } \\
\begin{array}{l}\text { Oral yeast } \\
\text { colonization } \\
\text { Oral fungal } \\
\text { infection }\end{array}\end{array}$ & $39(13.92)$ & $24(39.34)$ & $<0.001$ \\
\hline
\end{tabular}

Table 2. Correlation between salivary flow rate and oral yeast colonization/fungal infection

\begin{tabular}{|l|c|c|c|c|}
\hline & \multicolumn{4}{|c|}{ Salivary flow rate } \\
\hline & \multicolumn{2}{|c|}{$\begin{array}{c}\text { Institutionalized } \\
\text { elderly }\end{array}$} & $\begin{array}{c}\text { Non-institutionalized } \\
\text { elderly }\end{array}$ \\
\cline { 2 - 5 } & $\mathrm{r}$ & $\mathrm{p}$-value & $\mathrm{r}$ & $\mathrm{p}$-value \\
\hline $\begin{array}{l}\text { Oral yeast } \\
\text { colonization } \\
\text { and fungal } \\
\text { infection }\end{array}$ & -0.58 & $<0.05$ & -0.52 & $<0.05$ \\
\hline
\end{tabular}

$\mathrm{r}=$ Spearman's coefficient of correlation

Significantly higher levels of oral colonization with yeasts and oral fungal infection were found among the institutionalized elderly compared with the non-institutionalized group $(\mathrm{p}<0.001)$. Table 1 shows the results on mouth colonization with oral yeasts and presence of oral fungal infection. A negative correlation was observed between salivary flow rate and yeast colonization in both institutionalized ( $r s=-0.58 ; \mathrm{p}<0.05)$ and non-institutionalized ( $\mathrm{rs}=-0.52 ; \mathrm{p}<0.05)$ elderly. Results regarding these correlations are summarized in Table 2.

Data on dental conditions are shown in Table 3. Approximately half of the institutionalized elderly (47.85\%) were completely edentulous as compared with $29.5 \%$ in the non-institutionalized group (Table $3)$. There were no statistically significant differences between the two groups $(\mathrm{p}=0.091)$. Altogether, $23 \%$ of institutionalized elderly and $19 \%$ of non-institutionalized elderly were affected by caries. A significant difference in DMFT was observed between the groups 
Table 3. DMFT index, number of teeth, levels of decayed, missing and filled teeth in institiutionalized and non-institutionalized elderly

\begin{tabular}{|c|c|c|c|c|c|}
\hline \multirow[b]{2}{*}{ Elderly } & \multirow[b]{2}{*}{$\begin{array}{l}\text { DMFT index } \\
(\text { mean } \pm S D)\end{array}$} & \multicolumn{4}{|l|}{ Teeth } \\
\hline & & $\begin{array}{l}\text { Number } \\
(\text { mean } \pm \mathrm{SD})\end{array}$ & $\begin{array}{l}\text { Decayed } \\
(\text { mean } \pm \mathrm{SD})\end{array}$ & $\begin{array}{l}\text { Missing } \\
(\text { mean } \pm \mathrm{SD})\end{array}$ & $\begin{array}{l}\text { Filled } \\
(\text { mean } \pm \mathrm{SD})\end{array}$ \\
\hline Institutionalized & $24.08 \pm 3.81$ & $6.85 \pm 5.73$ & $0.53 \pm 0.92$ & $21.15 \pm 5.66$ & $2.38 \pm 2.72$ \\
\hline Non-institutionalized & $17.19 \pm 7.93$ & $14.38 \pm 8.74$ & $0.38 \pm 0.69$ & $13.61 \pm 8.74$ & $3.21 \pm 3.24$ \\
\hline $\mathrm{p}$-value & $<0.001$ & $<0.001$ & 0.307 & $<0.001$ & 0.098 \\
\hline
\end{tabular}

DMFT index = decayed, missing, filled teeth index

$(\mathrm{p}<0.001)$. Institutionalized elderly had significantly more missing teeth than non-institutionalized elderly $(p<0.001)$. The findings of decayed and missing teeth were more frequent among institutionalized elderly, although the difference between the two investigated groups was not statistically significant $(\mathrm{p}>0.05)$. Finally, there was a negative correlation between salivary flow rate and DMFT index in both the institutionalized $\left(\mathrm{r}_{\mathrm{s}}=-0.22 ; \mathrm{p}<0.05\right)$ and non-institutionalized $\left(\mathrm{r}_{\mathrm{s}}=-\right.$ $0.56 ; \mathrm{p}<0.05)$ groups of elderly (Table 2 ).

\section{Discussion}

Saliva has a significant role in maintaining the natural balance between oral host tissues and oral microflora ${ }^{19,24}$. Low salivary flow rate or hyposalivation is known to induce various problems including dental caries, periodontitis, denture problems, candidiasis, and mastication and swallowing problems ${ }^{11,21}$. The incidence of hyposalivation among the elderly ranges from $10 \%$ to $50 \%{ }^{25}$. Our results obtained in non-institutionalized elderly (Fig. 1) and hereby presented were in accordance with these data since it was demonstrated that the incidence of hyposalivation in the non-institutionalized elderly was 44\%. Our results also showed a significantly higher incidence (75\%) of decreased salivary flow rate in the institutionalized elderly (Fig. 1). These results are consistent with the results of an investigation conducted among nursinghome residents in Holland, which found low salivary flow rates in $72 \%$ of the institutionalized elderly ${ }^{26}$. Salivary gland hypofunction may be correlated with various systemic disorders, medications, as well as the number of medications ${ }^{3,11,27,28}$. The higher incidence of decreased salivary flow rate which we found in the group of institutionalized elderly could be the result of a rather high number of different medications or intake of medications with specific xerostomic side effects $^{27,28}$.

Regardless of the etiology of salivary gland hypofunction, changes in the oral ecology occur with unstimulated whole saliva flow rates below $0.20 \mathrm{~mL}$ per minute ${ }^{15}$. At such flow rates, oral microbial profile includes increased numbers of microorganisms which may lead to an increased risk of oral fungal infection and high caries activity ${ }^{15}$. This is due to the role of saliva in inhibiting oral microbial colonization ${ }^{11,15}$.

The mouth is a reservoir of yeasts and these fungi can be frequently isolated without related pathologic changes to the epithelium ${ }^{29}$. The incidence of yeast colonization in clinically normal mouth of healthy adults ranges from $3 \%$ to $48 \%{ }^{30}$. Previous reports suggest that yeasts can be isolated from oral cavity in 65\% to $88 \%$ of the elderly residing in acute or long-term facilities ${ }^{31}$. Altogether, $68.92 \%$ of institutionalized elderly in our study were positive for oral colonization with yeasts (Table 1 ). This result was statistically significantly different compared with the non-institutionalized elderly. The patients with low or impaired salivary flow had higher oral yeast counts when compared with the saliva from patients with normal salivary flow ${ }^{15,32}$. Our results were in accordance with these results since we found a negative correlation between oral yeast colonization and decreased salivary flow rate (Table 2). The results of our investigation also showed an increased number of the institutionalized elderly with oral fungal infection as compared with the non-institutionalized group (Table 1). Higher levels of oral yeast colonization and oral fungal infection in institutionalized elderly may be related to significantly lower salivary flow rates (and the associated reduction in salivary antimicrobial function), and may also be related to the poor oral and denture hygiene ${ }^{33,34}$. 
Hyposalivation has been associated with an increased incidence of caries in the elderly population $^{19,24}$. In addition, a diet high in refined carbohydrates and poor oral hygiene pose a considerable risk of caries especially among nursing home residents ${ }^{35}$. Approximately half of the institutionalized elderly in our study $(47.85 \%)$ were completely edentulous as compared with $29.5 \%$ among the non-institutionalized elderly. The incidence of edentulous persons among the institutionalized elderly found in this study was close to $45.3 \%$ found by Kraljevic et al. ${ }^{36}$. Our findings were lower compared to those obtained by De Visschere et al., who found that about two-thirds of the institutionalized elderly (64\%) were edentulous ${ }^{37}$, but higher than $26.9 \%$ reported by Tramini et al. ${ }^{38}$. The DMFT index of 24.08 among institutionalized elderly (Table 3) was lower than 26.6 found among institutionalized elderly in Canada ${ }^{35}$ and 30.75 found in Slovenia ${ }^{39}$. Our findings may also be related to the low salivary flow rate, as well as poor oral hygiene $\mathrm{e}^{11,18}$.

\section{Conclusion}

Our study evaluated a sample of the institutionalized and non-institutionalized elderly in Rijeka. Results of this study showed a higher prevalence of hyposalivation, oral yeast colonization and oral fungal infection among the institutionalized elderly as compared with the non-institutionalized group. We also found poorer dental status in the institutionalized elderly. This underscores the necessity of developing effective programs for improving oral health in this population group.

\section{Acknowledgments}

The study was supported by grant no. 818-10-1218 from the Croatian Ministry of Science, Education and Sports.

\section{References}

1. Gil-Montoya JA, Ferreira de Mello AL, Barrios R, et al. Oral health in the elderly patient and its impact on general wellbeing: a nonsystematic review. Clin Interv Aging. 2015;10: 461-67. doi: 10.2147/CIA.S54630. eCollection 2015.

2. Brocklehurst PR, Mackay L, Goldthorpe J, et al. Older people and oral health: setting a patient-centred research agenda. Gerodontology. 2015;32:222-8. doi: 10.1111/ger.12199.
3. Gaszynska E, Szatko F, Godala M, et al. Oral health status, dental treatment needs, and barriers to dental care of elderly care home residents in Lodz, Poland. Clin Interv Aging. 2014;9:1637-44. doi: 10.2147/CIA.S69790. eCollection 2014.

4. Issrani R, Ammanagi R, Keluskar V. Geriatric dentistry-meet the need. Gerodontology. 2012;29:e1-5. doi: 10.1111/j.1741 $-2358.2010 .00423 . x$.

5. Marin-Zuluaga DJ, Sandvik L, Gil-Montoya JA, et al. Oral health and mortality risk in the institutionalised elderly. Med Oral Patol Oral Cir Bucal. 2012;17:618-23.

6. Campisi G, Chiappelli M, De Martinis M, et al. Pathophysiology of age-related diseases. Immun Ageing. 2009;8:6-12. doi: 10.1186/1742-4933-6-12.

7. Gil-Montoya JA, De Mello AL, Candenas CB, et al. Oral health protocol for the dependent institutionalized elderly. Geriatr Nurs. 2006;27:95-101.

8. Ornstein KA, Decherrie L, Gluzman R, et al. Significant unmet oral health needs of homebound elderly adults. J Am Geriatr Soc. 2015;63:151-7. doi: 10.1111/jgs.13181.

9. Dawes C, Pedersen AM, Villa A, et al. The functions of human saliva: a review sponsored by the World Workshop on Oral Medicine VI. Arch Oral Biol. 2015;60:863-74. doi: 10.1016/j. archoralbio.2015.03.004.

10. Razak PA, Richard KM, Hankachan RP, et al. Geriatric oral health: a review article. J Int Oral Health. 2014;6:110-6.

11. Mortazavi H, Baharvand M, Movahhedian A, et al.Xerostomia due to systemic disease: a review of 20 conditions and mechanisms. Ann Med Health Sci Res. 2014;4:503-10. doi: 10.4103/2141-9248.139284

12. Scelza MF, Silva Dee F, Ahiazdro NK, et al. The influence of medication on salivary flow of the elderly: preliminary study. Gerodontology. 2010;27:278-82. doi: 10.1111/j.1741-2358. 2009.00326.x.

13. Vučičević Boras V, Andabak-Rogulj A, Brailo V, et al. Adverse drug reactions in the oral cavity. Acta Clin Croat. 2015;54: 208-15.

14. Tanasiewicz M, Hildebrandt T, Obersztyn I. Xerostomia of various etiologies: a review of the literature. Adv Clin Exp Med. 2016;25:199-206. doi: 10.17219/acem/29375.

15. Hofer E, Jensen SB, Pedersen AML, et al. Oral microflora in patients with salivary gland hypofunctions. Oral Biosci Med. 2004;1:93-107.

16. Yuan A, Woo SB. Adverse drug events in the oral cavity. Oral Surg Oral Med Oral Pathol Oral Radiol. 2015;119:35-47. doi: 10.1016/j.oooo.2014.09.009.

17. Niessen LC, Fedele DJ. Aging successfully: oral health for the prime of life. Compend Contin Educ Dent. 2002;23:4-11.

18. Brukiene V, Aleksejuniene J, Gairionyte A. Salivary factors and dental plaque levels in relation to the general health of elderly residents in a long-term care facility: a pilot study. Spec Care Dentist.2011;31:27-32.doi:10.1111/j.1754-4505.2010.00172.x. 
19. Larmas M, Sandor GK. Enzymes, dentinogenesis and dental caries: a literature review. J Oral Maxillofac Res. 2014;29:5(4). doi: 10.5037/jomr.2014.5403.

20. Navazesh M, Kumar SK. Measuring salivary flow: challenges and opportunities. J Am Dent Assoc. 2008;139:35-40.

21. Sreebny LM. Saliva in health and disease: an appraisal and update. Int Dent J. 2000;50:140-61.

22. Olsen I. Denture stomatitis. Occurrence and distribution of fungi. Acta Odontol Scand. 1974;32:329-33.

23. World Health Organization. Guide to epidemiology and diagnosis of oral mucosal diseases and conditions. Community Dent Oral Epidemiol. 1980;8:1-26.

24. Turner MD. Hyposalivation and xerostomia: etiology, complications, and medical management. Dent Clin North Am. 2016; 60:435-43. doi: 10.1016/j.cden.2015.11.003.

25. Turner MD, Ship JA. Dry mouth and its effects on the oral health of elderly people.J Am Dent Assoc. 2007;138:15-20.

26. Van Der Putten GJ, Brands HS, Bots CP, et al. Prevalence of xerostomia and hyposalivation in the nursing home and relation with number of prescribed medication. Tijdschr Gerodontol Geriatr. 2003;34:30-6.

27. Leal SC, Bittar J, Portugal A, et al. Medication in elderly people: its influence on salivary pattern, signs and symptoms of dry mouth. Gerodontology. 2010;27:129-33. doi: 10.1111/j.1741 -2358.2009.00293.x.

28. Ichikawa K, Sakuma S, Yoshihara A, et al. Relationships between the amount of saliva and medications in elderly individuals. Gerodontology. 2011;28:116-20. doi: 10.1111/j.1741 $-2358.2009 .00358 . x$.

29. Grimoud AM, Lodter JP. Improved oral hygiene and candida species colonization level in geriatrics patients. Oral Dis. 2005; 11:163-9.
30. Kulak-Ozkan Y, Kazazoglu E, Arikan A. Oral hygiene habits, denture cleanliness, presence of yeasts and stomatitis in elderly people. J Oral Rehab. 2002;29:300-4.

31. Garcia-Cuesta C, Sarrion-Perez MG, Bagan JV. Current treatment of oral candidiasis: a literature review. J Clin Exp Dent. 2014;6:576-82. doi: 10.4317/jced.51798.

32. Pereira-Cenci T, Del Bel Cury AA, Crielaard W, et al. Development of Candida-associated denture stomatitis: new insights. J Appl Oral Sci. 2008;16:86-94.

33. Zengin Az, Yanik K, Celenk P, et al. Oral hygiene and oral flora evaluation in psychiatric patients in nursing homes in Turkey. Niger J Clin Pract. 2015;18:751-6. doi: 10.4103/11193077.158142.

34. Ishihara K, Adachi M, Eguchi J, et al. Prevalence of staphylococcus species and Candida in the oral cavity of elderly who require daily care in a nursing home. Bull Tokyo Dent Coll. 2000;41:169-74.

35. Wyatt CCL. Elderly Canadians residing in long-term care hospitals: Part II. Dental caries status. J Can Dent Assoc. 2002;68:359-63.

36. Kraljević-Šimunković S, Vučičević Boras V, Pandurić J, et al. Oral health among institutionalized elderly in Zagreb, Croatia. Gerodontology. 2005;22:238-41.

37. De Visschere LM, Grooten L, Theuniers G, et al. Oral hygiene of elderly in long-term care institutions - a cross-sectional study. Gerodontology. 2006;23:195-204.

38. Tramini P, Montal S, Valcacel J. Tooth loss and associated factors in long-term institutionalised elderly patients. Gerodontology. 2007;24:196-203.

39. Petelin M, Cotic J, Perkic K, et al. Oral health of the elderly living in residential homes in Slovenia. Gerodontology. 2012; 29:447-57. doi: 10.1111/j.1741-2358.2011.00497.x.

Sažetak

\section{LUČENJE SLINE, KOLONIZACIJA USNE ŠUPLJINE KVASNICAMA I DENTALNI STATUS U STARIJIH OSOBA SMJEŠTENIH U USTANOVI I ONIH KOJE ŽIVE SAMOSTALNO}

\section{Glažar, M. Mubvić Urek, D. Kuiš, J. Prpić, I. Mišković, D. Kovačević Pavičić i S. Pezelj-Ribarić}

Osobe starije životne dobi podložnije su razvoju oralnih bolesti, a osobito su osjetljive osobe smještene u ustanove za starije i nemoćne. Cilj ovoga istraživanja bio je utvrditi dentalni status, razinu lučenja sline i infekciju usne šupljine kvasnicama kod starijih osoba. Istraživanje je uključivalo 341 ispitanika, 280 osoba smještenih u ustanovi i 61 osobu koja živi samostalno. Između skupina uspoređivana je količina izlučene sline, kolonizacija odnosno oralna infekcija kvasnicama i dentalni status. Kod osoba smještenih u ustanovi za starije i nemoćne zabilježena je značajno niža razina lučenja sline $(\mathrm{p}=0,035)$ te češća kolonizacija i infekcija kvasnicama $(p<0,001)$. Utvrđena je negativna korelacija između snižene razine lučenja sline i oralne kolonizacije kvasnicom odnosno gljivične infekcije kod obje skupine ispitanika, tj. za osobe smještene u ustanovama $(r s=-0,58 ; p<0,05)$ kao i za osobe koje žive samostalno ( $r s=-0,52 ; p<0,05)$. Između skupina nađena je značajna razlika $u$ indeksu KEP $(\mathrm{p}<0,001)$. Također je zabilježena negativna korelacija između smanjenog lučenja sline i dentalnog statusa kod osoba u ustanovama $(r s=-0,22 ; \mathrm{p}<0,05)$ kao i kod osoba koje žive samostalno $(\mathrm{rs}=-0,56 ; \mathrm{p}<0,05)$. Rezultati istraživanja ukazuju na značajno nižu razinu lučenja sline, veću učestalost kolonizacije i infekcije kvasnicom usne šupljine te lošiji dentalni status kod osoba smještenih u ustanovama.

Ključne riječi: Starija osoba; Kserostomija; Gljivice; Oralne bolesti; Indeks KEP 